\title{
Dynamic and integrative aspects of the regulation of reproduction by metabolic status in male sheep
}

\author{
Dominique BlachE*, Song ZHANG, Graeme B. MARTIN \\ School of Animal Biology M085, Faculty of Natural and Agricultural Sciences, The University of \\ Western Australia, Crawley 6009, Western Australia
}

\begin{abstract}
Change in metabolic status, defined as a change in the availability of nutrients and energy to the tissues, is a powerful regulator of the reproductive function in small ruminants, especially in genotypes that are not strongly responsive to photoperiod such as the Merino sheep. In this paper, the dynamics of the response of the reproductive axis to changes in metabolic status are reviewed in the light of recent studies. The nature and the roles of the various components of the pathways linking metabolic status to reproduction are considered: nutrients and metabolites, the endocrine system, and the nervous system. We discuss the role of leptin and insulin in detail because of the central role of these two hormones in both the early gonadotrophin response to increase in nutrition and the long-term response of the testis to dietary stimulation. The possible roles of recently identified peptides, such as ghrelin and kisspeptin, are also considered as we develop a general hypothesis that encompasses the different levels of integration necessary to explain the complex interactions between reproductive function and metabolic status, and the possible existence of a "metabolic memory" in this interaction.
\end{abstract}

nutrition / GnRH / LH / leptin / insulin / testis

\section{INTRODUCTION}

In sheep and goats, reproductive activity is affected by a range of external factors, including socio-sexual cues, photoperiod and metabolic status (reviews: [1,2]). Metabolic status is defined as the amount of nutrients and energy available to the animal's tissues at a given time, and it depends on three factors: the mass of food consumed, the mass of body reserves and the rate of expenditure of energy. Importantly, changes in any of these three components can influence the reproductive capacity in both males and females [3,4]. This review aims at shedding light upon the signalling systems involved in the regulation of repro-

\footnotetext{
* Corresponding author:

dbla@animals.uwa.edu.au
}

ductive function by changes in metabolic status, with a focus on male ruminants. We begin by focussing on the metabolic target in the reproductive axis and then we describe the concept of metabolic status and its links to reproductive function. The response of the reproductive axis to an acute increase in food intake is used to illustrate the dynamic and integrative nature of the relationship between metabolic status and reproductive activity. We then review the role of three different classes of control systems - nutrients, endocrine and nervous systems - and illustrate the interactions within and between these systems. Finally, the regulation of reproductive function is placed in perspective with the action of other external factors that also control reproduction. 


\section{THE KEY METABOLIC TARGET IN THE REPRODUCTIVE AXIS}

The most fundamental driver of reproductive function is the hypothalamicpituitary gonadal axis. Hypothalamic gonadotrophin-releasing hormone $(\mathrm{GnRH})$ controls the secretion of both luteinising hormone (LH) and follicle-stimulating hormone (FSH), the principal factors that regulate the production of spermatozoa and hormones by the testis. The frequency of $\mathrm{GnRH}$ pulses, and consequently $\mathrm{LH}$ pulses, is the code used by the nervous system to control gonadal function. The network of neurons that controls GnRH secretion is thought to be the most direct pathway via which many factors influence gonadal activity, including metabolic status (review: [2]). It has to be noted that the pituitary gland and the testis can also respond independently to metabolic status.

\section{METABOLIC STATUS}

The amount of energy available to the tissues at a given time depend on the difference between the pool of disposable energy and the pool of expended energy. The pool of disposable energy includes the energy derived from nutrition but also the energy stored in body tissues, especially adipose tissue, a highly efficient storage system. The pool of expended energy varies according to the age and the physiological status of the animal and it comprises the energy spent on functions that are responsible for the maintenance of homeostasis and also energy spent on extra physiological needs such as growth and reproduction. The components of both pools are affected by internal factors (e.g., fever, reproductive activity) and external factors (e.g., ambient temperature, food availability) so these factors also affect energy balance.

\section{EFFECTS OF VARIATION IN METABOLIC STATUS ON REPRODUCTIVE FUNCTION}

Changes in metabolic status can act at any of the three levels of the reproductive axis (hypothalamus, pituitary gland, gonads) as well as on the regulatory feedback mechanisms. In mature male sheep, an increase in the intake of energy and protein induces, at first, an increase in the frequency of pulses of GnRH and $\mathrm{LH}$, and in the tonic secretion of FSH. The response of the GnRH neurons to nutrition is initially rapid but then varies as time progresses ([5,6], Fig. 1). In the mature Merino ram, an increase in intake stimulates the release of pulses of $\mathrm{GnRH} / \mathrm{LH}$ within only 5-6 h [6] and the high frequency of LH pulses is maintained for about 3 weeks, but then fades away even if the rams are consuming the same large amount of energy and nutrients [5]. Plasma concentrations of FSH are also increased, although there is a delay of about 10 days. Conversely, a reduction of feed intake reduces $\mathrm{LH}$ pulse frequency [4]. In the long-term, a sustained increase in nutrition leads to an increase in both testis size and sperm production [7]. Recently, we have shown that the responsiveness of the GnRH neurons to an acute increase in feed supply depends on the amount of reserves (or the previous level of intake) because, in fat rams, $\mathrm{LH}$ pulse frequency is not stimulated by an increase in nutrient and energy intake that stimulates LH pulse frequency in lean rams (Fig. 2). These observations suggest that the signalling pathway is multifactorial and able to integrate at least two compartments of the metabolic status, the intake and the fat reserve.

\section{THE SIGNALLING PATHWAYS}

Both of the classical control systems, the endocrine and nervous systems, are 

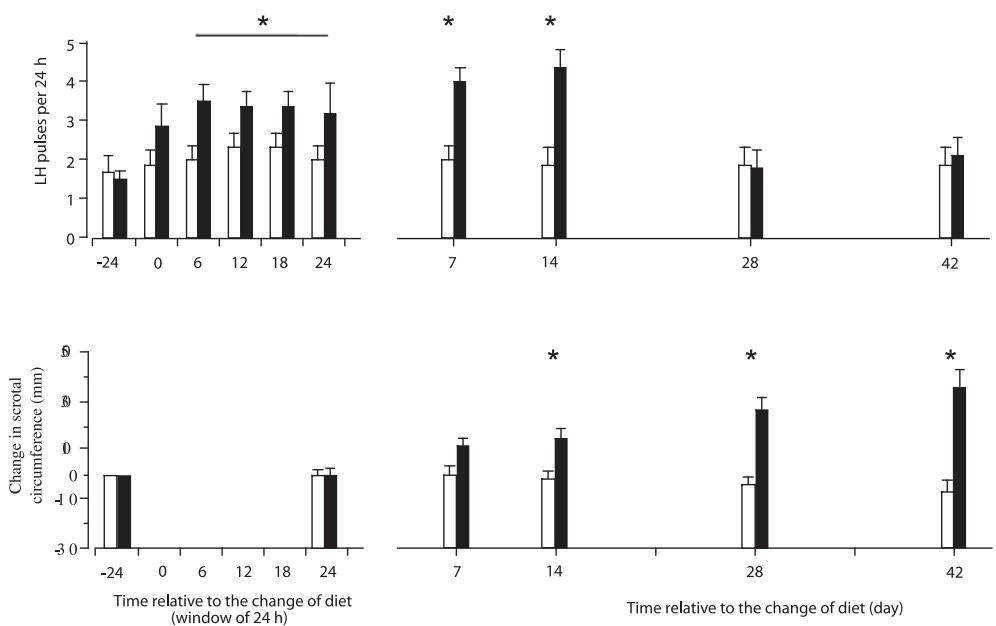

Figure 1. Schematic representation of the effect of an acute increase in the supply of dietary protein and energy on the pulsatile secretion of LH and testis size. Rams were fed a maintenance diet that maintains bodyweight constant $(\square)$ or fed a high energy and protein diet (ם). Adapted from $[6,68]$.
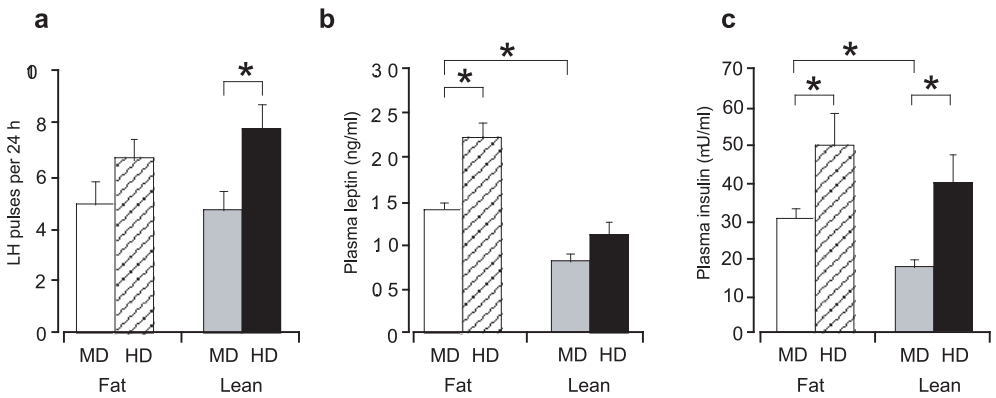

Figure 2. LH pulse frequency and plasma concentrations of leptin and insulin after an increase of protein and energy intake in lean and fat adult Merino rams. Adapted from [25]. MD: maintenance diet, HD: High energy and protein diet.

involved in responding to metabolic status and then programming the reproductive axis. In addition, nutrient metabolites produced by digestion or by anabolic processes are also involved.

\subsection{Nutrients and metabolites as signals}

During digestion, food is broken down, with the help of rumen bacteria in ruminants, into nutrients that can either be absorbed or passively diffused through the wall of elements of the digestive tract and flow into the circulation. In ruminants, the critical substances are fatty acids (volatile or non-volatile), amino acids and carbohydrates.

\subsubsection{Fatty acids}

In ruminants, plasma concentrations of volatile fatty acids increase with an increase in feeding regime and, in most 
cases, negative energy balance induces an increase in plasma non-esterified fatty acids (NEFA), $\beta$-hydroxybutyrate and ketone bodies. In male sheep, adding exogenous fatty acids to a maintenance diet increases LH pulse frequency, but the response is smaller than with grain supplements $[8,9]$, suggesting that fatty acids are only part of the signal that affects gonadotrophin secretion. The rapid absorption of the volatile fatty acids through the rumen wall [10] could be an early signal and may be involved in eliciting the initial, rapid response of the GnRH neurons to an increase in the plane of nutrition. We have never measured the production of VFA immediately after an acute increase in nutrition, but we know that infusion of a mixture of VFA does not induce a rapid increase in secretion of insulin [11]. Alternatively, the action of VFA on the reproductive axis could be mediated by leptin because it has been shown that, within $2 \mathrm{~h}$, a short intravenous infusion of propionate $(30 \mathrm{~min})$ stimulates leptin mRNA expression in ovine adipose tissue [12]. Moreover, the same short infusion of propionate induces a rapid and large increase in plasma concentrations of both insulin and glucose [12]. VFA could act on hormonal systems to stimulate the reproductive axis but this effect does not seem to be enough to produce an increase in $\mathrm{LH}$ pulse frequency that is similar in size to that observed after an acute increase in protein and energy intake $[8,9]$.

\subsubsection{Amino acids}

In male sheep, ten days of high food intake leads to increases in the concentrations of arginine, phenylalanine, proline, tyrosine, methionine and phosphoserine in both plasma and cerebrospinal fluid, whereas aspartate and serine concentrations increase only in plasma [13]. Most of the amino acids that are affected by changes in the diet do not seem to be important in the GnRH response because, in female sheep, intravenous infusion of precursors of neurotransmitters of largeneutral amino acids does not affect $\mathrm{LH}$ secretion [14-16]. In any case, it is difficult to see why normal aspects of brain function would depend on day-to-day fluctuations in the availability of one or a few amino acids. Moreover, only the amino acids produced by the digestion of protected proteins, not degraded by rumen bacteria and absorbed within a few hours, could be involved in the very early response of the reproductive axis [10]. In our lupin-fed model, the majority of proteins are processed by the rumen bacteria so the rate of absorption of amino acids into the circulatory system is too slow for them to stimulate the reproductive centre with 5$6 \mathrm{~h}$ [10]. However, a role for animo acids in the long-term response to nutrition by the reproductive axis is very probable.

\subsubsection{Glucose}

Glucose was an early candidate as a metabolic link between nutrition and reproduction [17]. In sheep, administration of glucose reverses the inhibition of LH secretion that is induced by insulin-induced hypoglycaemia in ewes $[18,19]$ and by growth-restriction in wethers [20]. In addition, in lambs, 2-dexoxy-glucose, a competitive inhibitor of glycolysis, decreases LH pulse frequency to values typically seen in undernourished animals [21]. However, the role of glucose is not clear in mature male sheep. In rams fed a low energy diet, intra-abomasal and intravenous infusions of glucose do not stimulate pulsatile LH secretion ([9, 22, 23], Fig. 3). These studies appear contradictory, but the mechanisms that decrease GnRH activity in the virtual absence of glucose from the whole brain (as with the studies using insulin or 2-dexoxy-glucose) might differ from those 


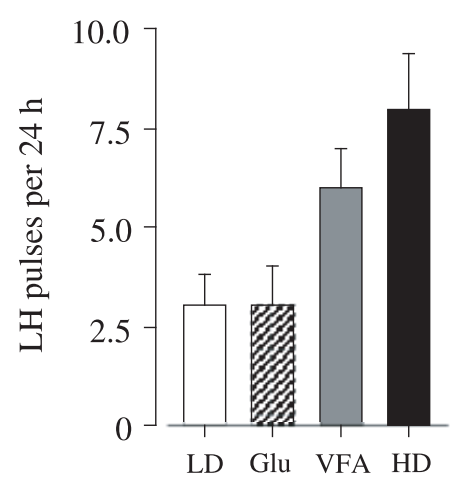

Figure 3. LH pulse frequency in rams fed a low energy and protein diet $(\square, 9 \mathrm{MJ}$ and $69 \mathrm{~g}$ of crude protein/day), or fed the same diet and supplemented with volatile fatty acids ( $\not Z Z)$, or infused intravenously with glucose ( $\square)$, or fed a high energy and protein diet ( $\square$ ). All the treatments lasted for 5 days. (Adapted from [69-71].)

activated by a 'normal' change in food intake. We are convinced that it is unlikely that glucose is part of the signalling system by which an acute increase in nutrition induces an increase in GnRH pulse frequency.

\subsection{Endocrine systems}

All hormonal systems involved in the control of metabolism or the control of feed intake have been proposed as regulators to the reproductive axis in relation of long-term or short-term change in metabolic status. However, in studies with male ruminants, the results obtained by manipulating one hormonal system at a time are not always conclusive. In the following section, the role of some endocrine systems that are sensitive to change in metabolic status will be described independently of each other. This rather unrealistic approach is necessary before we enter the next section of this review in which the dynamic and integrative aspects of the various regulatory systems are discussed.

\subsubsection{Thyroid hormones}

Thyroxine and tri-iodothyronine are involved in tissue differentiation and growth, and in the regulation of numerous bodily functions, mainly by affecting metabolic rate. Thyroid hormones have a role in the control of seasonal reproduction in sheep [24]. However, there is very little evidence suggesting that thyroid hormones are part of the signalling pathway linking energy balance and reproduction. In the mature male sheep, thyroid hormones in plasma and CSF are not affected by the acute increases in nutrition that are associated with increases in LH pulse frequency, suggesting that they have no role in the rapid response of the GnRH neurons [6,13,25].

\subsubsection{Insulin}

Insulin is, however, affected by energy balance and seems to be involved in the control of reproduction in male ruminants because of the following: (1) male sheep fed on a high plane of nutrition have high concentrations of insulin in both plasma and CSF $[6,13,25]$; (2) in rams fed on a low diet and in diabetic sheep, infusion of a low dose of insulin into the third ventricle increases LH pulse frequency to values similar to those seen in well-fed rams [26-28]; (3) insulin can act at the brain level where its receptor is present in the hypothalamus [29]; (4) in rams acutely fed a high diet, the increase in insulin secretion coincides with the start of the increase in $\mathrm{LH}$ pulse frequency [6]. Therefore, the accumulated evidence is very strong for a major role for insulin in the rapid GnRH response.

\subsubsection{Growth Hormone}

The presence of mRNA for GH receptors in the hypothalamus and the pituitary gland $[30,31]$ has raised the possibility that 
GH plays a role in the link between nutrition and gonadotrophin secretion [32]. In ruminants, energy balance affects plasma concentrations of GH under a wide variety of experimental conditions [33] but, in male sheep, it does not seem to be involved in the stimulation of GnRH secretion because an increase in nutrition induces a decrease in plasma GH concentrations [13]. GH has, however, been suggested to have a role in the long-term effect on nutrition of the testicular function [34].

\subsection{Insulin-like growth factor-I (IGF-I)}

In castrated male sheep, peripheral administration of physiological doses of IGF-I stimulates LH secretion [35]. However, in the mature, testis-intact male sheep, peripheral concentrations of IGF-I are affected by diet, but CSF concentrations are not [13] and we have not been able to demonstrate that IGF-I infusion into the third ventricle affects LH pulse frequency (Blache, unpublished data). It therefore seems likely that, in mature testis-intact males at least, IGF-I does not act as a central mediator of nutritional status to the reproductive centres.

\subsection{Leptin}

Over the past decade in particular, the view of the role of adipose tissue in the management of metabolic status has changed from that of a passive energy reserve to that of a very active endocrine regulator of a multitude of bodily functions, including food intake, metabolism, immunity, thermoregulation, cardiovascular function and reproduction [36-38]. Of the 20 or more secretory products of adipose tissue, leptin appears to be the most important regulator of reproductive activity in laboratory species [39] and in ruminants (for review see [40]). Both short-term and long-term changes in metabolic status alter the expression and release of leptin, and also the sensitivity of gonadal and brain tissues to leptin. Moreover, numerous experiments in female and male sheep have shown that leptin can affect the neuroendocrine systems that control the activity of the reproductive axis (for review see [41]). However, there is a consensus amongst authors that the role of leptin is permissive rather than triggering, and this is logical because adipose tissue is only one of the three components of metabolic status. This view is now common for the onset of puberty in rodents, humans, cows and sheep [42-44].

\subsection{Nervous systems}

There is little, if any, information on the role of the autonomic system in the regulation of reproductive function by metabolic status, yet the various stages of the reproductive process must be coordinated with most if not all homeostatic processes. We will not ignore this major control system and we will deal with it in the next section where we consider dynamic and integrative aspects of the link between metabolism and reproduction. By contrast, the role of the central nervous system in coordinating reproduction with metabolic status is clearly understood, probably because it exerts primary and immediate control over the reproductive axis through the pulsatile secretion of GnRH. Despite considerable research effort, the brain mechanisms involved in the sensing of metabolic status and in the connection of metabolic status to the GnRH neurons are still poorly understood. The metabolic sensor is thought to be localised in the arcuate nucleus and median eminence because receptors for leptin and insulin are found in these sites $[29,40]$ and because the centres involved in the control of intake are also nearby $[45,46]$. However, in the monkey and rat, insulin 


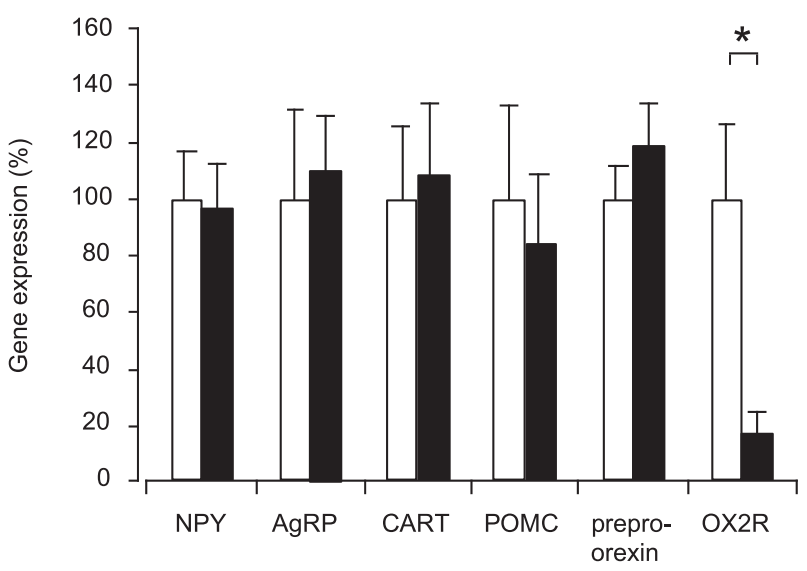

Figure 4. Relative gene expression for neuropeptide Y (NPY), agouti-related peptide (AgRP), cocaine- and amphetamine-regulated transcript (CART) and pro-opiomelanocortin (POMC) in the arcuate nucleus, and for prepro-orexin in the lateral hypothalamic area and OX2R in the paraventricular nucleus (PVN) of the hypothalamus of rams fed a maintenance diet (MD) that maintains bodyweight constant $(\square)$ and in rams fed $50 \%$ more than the maintenance diet $(\square)$. Values are expressed as percentages of values in rams fed MD (mean \pm SEM). $* P<0.05$.

and leptin receptors are not co-localised in the GnRH neurons [47] and the neural pathway between is still not identified. As a starting point, the neuropeptides known to be involved in the control of intake seem to be logical links [48] and they were first investigated because of anatomical evidence in sheep. In castrated sheep, leptin receptors are co-localised with neuropeptide Y (NPY) and pro-opiomelanocortin (POMC) in a large population of neurons (60 to $80 \%$ ) and in all neurons containing melanin-concentrating hormone and prepro-orexin [49]. These anatomical relationships might be related only to the control of food intake because in-situ hybridisation studies in sheep suggest that none of them were affected by change in intake within either a few hours or a few days, when the increase in LH pulse frequency is stable (Fig. 4). The search for a link between the GnRH cells and the neurons containing insulin and leptin receptors is continuing and there are many candidate signals. Among the most promising are the orexins because of their sensitiv- ity to energy balance [50] but intracerebral injections of orexin A or B do not stimulate $\mathrm{GnRH} / \mathrm{LH}$ secretion in mature Merino rams [1]. The roles of the orexinergic pathways need to be investigated further because high intakes of energy and protein reduce dramatically the expression of orexin receptor 2 in the paraventricular nucleus (Fig. 4). However, we have not yet demonstrated whether this change in sensitivity to orexins is related to a change in activity of the reproductive axis rather than to the control of intake. Recently, a new neuropeptide, kisspeptin, has been shown to stimulate GnRH and FSH secretion in male rodents [51-53]. Importantly, the kisspeptin receptor is found in over $75 \%$ of $\mathrm{GnRH}$ neurons in male rats [51] but it has still not been demonstrated that kisspeptin secretion or expression is regulated by energy balance and can stimulate the release of GnRH.

In summary, the pathways responsible for the integrative role played by the central nervous system is still far from being clear. Most of the research has centered on 
the mediobasal hypothalamus and preoptic area, where the GnRH cells are localised, but there is evidence that noradrenergic afferents from the brainstem could also be involved, because leptin receptors have been localised in this region and noradrenergic fibres projected to the preoptic area [54]. A down-side in our experimental model, rams acutely fed a large amount of energy, and in other fasting or starving models, is that changes in expression of neuropeptides are not necessarily related to the stimulation of the reproductive axis but can be only related temporally to the regulation of appetite. Injection or infusion of candidate neuropeptides into the intracerebral ventricles is the next logical step to establish a link to the regulation of $\mathrm{GnRH}$ secretion but doses and time-courses are not readily estimated and make these experiments difficult to interpret.

\section{TOWARDS THE INTEGRATION OF PATHWAYS}

Outside the central nervous system, other levels of integration are needed because metabolic status at any given time depends on the levels of the key compartments - intake, storage and expenditure - and their activities and the interrelationships among them are managed by several hormonal systems. For example, leptin, the secretion of which is affected by the mass of fat stores, by intake and by expenditure, can stimulate the secretion of the following: (1) insulin from the pancreas in fasted cattle but only at a low dose (20 $\mu \mathrm{g} \cdot \mathrm{kg}^{-1}$ : [55]); (2) GH in female sheep [56] but apparently not cattle [44]; and (3) thyroid hormones in cattle.

An acute increase in nutrition evokes a surge of leptin with one hour and stimulates GnRH secretion within hours [6] and the rapidity of these effects is consistent with the autonomic nervous system being involved in the responses of both the brain centres and adipose tissue. This could involve input from the gut to the brain via the vagus nerve, as is the case for satiety responses following a meal [46].

The long-term effect of nutrition on the testis has been suggested to involve $\mathrm{GH}$ [34] but the mechanism of action has not been studied further. Again, leptin could be involved because its receptor is present in the testis of rat [57] and leptin can inhibit stereogenesis in the testis of rat [58]. In addition, the secretion of ghrelin, a gut hormone that is the endogenous ligand of the GH secretagogue (GHS) receptor, is sensitive to nutrition. An increase in feed intake decreases ghrelin secretion but fasting increases plasma concentrations of ghrelin [59] and the distribution of GHS receptors overlaps that of GnRH in the arcuate nucleus [60]. Moreover, ghrelin decreases the secretion of $\mathrm{LH}$ in gonadectomised male rats [61], and ghrelin and GHS receptors are expressed in human and rat testis [62]. These observations support the suggestion that ghrelin mediates long-term effects of nutrition on testicular function since ghrelin, like leptin, can also stimulate prolactin secretion [62, 63]. However, the role of ghrelin in the testis, pituitary gland and brain is yet to be investigated in the model of the mature Merino male sheep.

In both sheep and cattle, previous metabolic status influences the response of the animals to an increase in energy availability. With respect to adipose stores, fat, mature male sheep do not show an increase in LH pulse frequency in response to an increase in intake whereas thin animals do [25]. Similarly, leptin stimulates LH secretion from pituitary explants of normal-fed cows but not from fasted cows [64]. With respect to energy expenditure, infusion of insulin increases leptin secretion in sheep kept in their thermal neutral zone but not in sheep enduring cold stress [65]. Together these observations suggest that the action of leptin or insulin on the reproductive axis depends on a "metabolic memory" 
[40]. If this is the case, then we need at least one other pathway, accounting for this "metabolic memory", with inputs into the regulatory pathways through which leptin and insulin affect GnRH output. Nutrients, such as short-chain fatty acids and glucose, could be part of this "metabolic memory pathways" because they are known to regulate leptin secretion in cultured adipocytes in ruminants (review: [40]). Hormonal factors secreted by adipose tissues or the digestive system could also be part of this integrative pathway. For example, several metabolic effects have been described for adiponectin in rodents, such as increased insulin resistance and fatty acid oxidation and reduced glucose output in the liver (review: [66]). These interactions between the endocrine system and nutrient supply may be peripheral integrative mechanisms that complement brain integrative mechanisms.

Finally, external factors can also modulate the effect of metabolic status on reproductive function - for example, photoperiod can override the influence of metabolic status in breeds that are living under high-amplitude changes in daylength where food availability is not a limiting factor at certain times of the year [1]. Once again, leptin seems to play an important role because its action on the reproductive axis varies with season in sheep $[27,67]$.

\section{CONCLUSION}

Metabolic status controls the reproductive capacity of male Merino sheep at the levels of the hypothalamus, pituitary gland and testis. The target sites within the reproductive axis change with time after a change of nutrition: the hypothalamic sites that control GnRH output are activated first and testicular sites are targeted later. The response of the GnRH neurons can be extremely rapid, faster than the digestive process, and seems to be influenced by "metabolic memory". The nature of the signals involved in either the timedependent response or the "memory" are not yet understood, but it is becoming clearer that leptin and insulin are key players in these regulatory processes. There must, however, be input from other signals, such as the fuel molecules, and the autonomic nervous system may also be involved in the integrated regulation of the different elements of metabolic status.

\section{REFERENCES}

[1] Blache D, Zhang S, Martin GB. Fertility in males: modulators of the acute effects of nutrition on the reproductive axis of male sheep. In: Campbell BK, Webb R, Dobson H, Doberska C (Eds), Reproduction in Domestic Ruminants V, Society for Reproduction and Fertility, Cambridge, 2003, p 387-402.

[2] Martin GB, Rodger J, Blache D. Nutritional and environmental effects on reproduction in small ruminants. Reprod Fertil Develop 2004, 16: 491-501.

[3] Bronson FH. Mammalian reproduction: an ecological perspective. Biol Reprod 1985, 32: 1-26.

[4] Martin GB, Walkden-Brown SW. Nutritional influences on reproduction in mature male sheep and goats. J Reprod Fertil Suppl 1995, 49: 437-449.

[5] Martin GB, Fisher JS, Blackberry MA, Boukhliq R, Hötzel MJ, Shepherd K, Walkden-Brown SW. Nutritional and photoperiodic control of testicular size in Suffolk and Merino rams. Proc Aust Soc Anim Prod 1994, 20: 427.

[6] Zhang S, Blache D, Blackberry MA, Martin GB. Dynamics of the responses in secretion of LH, leptin and insulin following an acute increase in nutrition in mature male sheep. Reprod Fertil Develop 2004, 16: 823-829.

[7] Oldham CM, Adams NR, Gherardi PB, Lindsay DR, MacKintosh JB. The influence of level of feed intake on sperm-producing capacity of testicular tissue in the ram. Aust J Agric Res 1978, 29: 173-179.

[8] Boukhliq R, Martin GB, White CL, Blackberry MA, Murray PJ. Role of glucose, fatty acids and protein in regulation 
of testicular growth and secretion of gonadotrophin, prolactin, somatotrophin and insulin in the mature ram. Reprod Fertil Dev 1997, 9: 515-524.

[9] Boukhliq R, Martin GB. Administration of fatty acids and gonadotrophin secretion in the mature ram. Anim Reprod Sci 1997, 49: 143-159.

[10] Annison EF, Lindsay DB, Nolan JV. Digestion and metabolism. In: Freer M, Dove $\mathrm{H}$ (Eds), Sheep nutrition, CAB International, Wallingford, 2002, p 95-118.

[11] Blache D, Chagas LM, Blackberry MA, Vercoe PE, Martin GB. Metabolic factors affecting the reproductive axis in male sheep. J Reprod Fert 2000, 120: 1-11.

[12] Lee SH, Hossner KL. Coordinate regulation of ovine adipose tissue gene expression by propionate. J Anim Sci 2002, 80: 28402849.

[13] Miller DW, Blache D, Boukhliq R, Curlewis JD, Martin GB. Central metabolic messengers and the effects of diet on gonadotrophin secretion in sheep. J Reprod Fertil 1998, 112: 347-356.

[14] Downing JA, Joss J, Scaramuzzi RJ. A mixture of the branched chain amino acids leucine, isoleucine and valine increases ovulation rate in ewes when infused during the late luteal phase of the oestrous cycle: an effect that may be mediated by insulin. J Endocrinol 1995, 145: 315-323.

[15] Downing JA, Joss J, Scaramuzzi RJ. The effects of N-methyl-D,L-aspartic acid and aspartic acid on the plasma concentration of gonadotrophins, $\mathrm{GH}$ and prolactin in the ewe. J Endocrinol 1996, 149: 65-72.

[16] Downing JA, Joss J, Scaramuzzi RJ. Ovulation rate and the concentrations of $\mathrm{LH}, \mathrm{FSH}, \mathrm{GH}$, prolactin and insulin in ewes infused with tryptophan, tyrosine or tyrosine plus phenylalanine during the luteal phase of the oestrous cycle. Anim Reprod Sci 1997, 45: 283-297.

[17] Schillo KK. Effects of dietary energy on control of luteinizing hormone secretion in cattle and sheep. J Anim Sci 1992, 70: 1271-1282.

[18] Clarke IJ, Horton RJE, Doughton BW. Investigation of the mechanism by which insulin-induced hypoglycemia decreases luteinizing hormone secretion in ovariectomized ewes. Endocrinology 1990, 127: 1470-1476.

[19] Funston RN, Roberts AJ, Hixon DL, Hallford DM, Sanson DW, Moss GE. Effect of acute glucose antagonism on hypophyseal hormones and concentrations of insulinlike growth factor (IGF)-I and IGF-binding proteins in serum, anterior pituitary, and hypothalamus of ewes. Biol Reprod 1995, 52: 1179-1186.

[20] Branum JC, Kline RS, Whisnant CS. The effects of neurotransmitter antagonists and glucose on luteinizing hormone secretion in growth-restricted wethers. Anim Reprod Sci 1997, 45: 263-272.

[21] Nagatani S, Bucholtz DC, Murahashi K, Estacio MA, Tsukamura H, Foster DL, Maeda KI. Reduction of glucose availability suppresses pulsatile luteinizing hormone release in female and male rats. Endocrinology 1996, 137: 1166-1170.

[22] Miller DW, Blache D, Martin GB. Neuroendocrine mediation of the effects of nutrition on the reproductive system: another task for insulin? Western Australian Endocrine Sciences Symposium, Perth, 1995.

[23] Boukhliq R, Miller DW, Martin GB Relationships between the nutritional stimulation of gonadotrophin secretion and peripheral cerebrospinal fluid (CSF) concentrations of glucose and insulin in rams. Anim Reprod Sci 1996, 41: 201-204.

[24] Karsch FJ, Dahl GE, Hachigian TM, Thrun LA. Involvement of thyroid hormones in seasonal reproduction. J Reprod Fertil Suppl 1995, 49: 409-422.

[25] Zhang S, Blache D, Blackberry MA, Martin GB. Body reserves affect the reproductive endocrine responses to an acute change in nutrition in mature male sheep. Anim Reprod Sci 2005, 88: 257-269.

[26] Miller DW, Blache D, Martin GB. The role of intracerebral insulin in the effect of nutrition on gonadotrophin secretion in mature male sheep. J Endocrinol 1995, 147: 321329.

[27] Miller DW, Findlay PA, Morrison MA, Raver N, Adam C.L. Seasonal and dosedependent effects of intracerebroventricular leptin on LH secretion and appetite in sheep. J Endocrinol 2002, 175: 395-404.

[28] Tanaka T, Nagatani S, Bucholtz DC, Ohkura $\mathrm{S}$, Tsukamura $\mathrm{H}$, Maeda K, Foster DL. Central action of insulin regulates pulsatile luteinizing hormone secretion in the diabetic sheep model. Biol Reprod 2000, 62: 12561261.

[29] Blache D, Adam CL, Martin GB. The mature male sheep: a model to study the effects 
of nutrition on the reproductive axis. In: Skinner DC, Evans NP, Doberska C (Eds), Large mammals as neuroendocrine models, Society for Reproduction and Fertility, Cambridge, Reproduction Suppl 2002, 59: 219-233.

[30] Kirby CJ, Thatcher WW, Collier RJ, Simmen FA, Lucy MC. Effects of growth hormone and pregnancy on expression of growth hormone receptor, insulin-like growth factor-I, and insulin-like growth factor binding protein- 2 and -3 genes in bovine uterus, ovary, and oviduct. Biol Reprod 1996, 55: 996-1002.

[31] Lucy MC, Boyd CK, Koenigsfeld AT, Okamura CS. Expression of somatotropin receptor messenger ribonucleic acid in bovine tissues. J Dairy Sci 1998, 81: 1889-1895.

[32] Monget P, Martin GB. Involvement of insulin-like growth factors in the interactions between nutrition and reproduction in female mammals. Human Reproduction 1997, 12 (Suppl 1): 33-52.

[33] Bossis I, Wettemann RP, Welty SD, Vizcarra JA, Spicer LJ, Diskin MG. Nutritionally induced anovulation in beef heifers: ovarian and endocrine function preceding cessation of ovulation. J Anim Sci 1999, 77: 15361546.

[34] Hötzel MJ, Walkden-Brown SW, Blackberry MA, Martin GB. The effect of nutrition on testicular growth in mature Merino rams involves mechanisms that are independent of changes in GnRH pulse frequency. J Endocrinol 1995, 147: 75-85.

[35] Adam CL, Findlay PA, Moore AH. Effects of insulin-like growth factor- 1 on luteinizing hormone secretion in sheep. Anim Reprod Sci 1998, 50: 45-56.

[36] Kershaw EE, Flier JS. Adipose tissue as an endocrine organ. J Clin Endocrinol Metab 2004, 89: 2548-2556.

[37] Ahima RS. Central actions of adipocyte hormones. Trends Endocrinol Metab 2005, 16: 307-313.

[38] Cinti S. The adipose organ. Prostaglandins, Leukot Essent Fatty Acids 2005, 73: 9-15.

[39] Krug AW, Ehrhart-Bornstein M. Newly discovered endocrine functions of white adipose tissue: possible relevance in obesityrelated diseases. Cell Mol Life Sci 2005, 62: 1359-1362.

[40] Chilliard Y, Delavaud C, Bonnet M. Leptin expression in ruminants: Nutritional and physiological regulations in relation with en- ergy metabolism. Domest Anim Endocrinol 2005, 29: 3-22.

[41] Adam CL, Archer ZA, Miller DW. Leptin actions on the reproductive neuroendocrine axis in sheep. Reprod Suppl 2003, 61: 283 297.

[42] Foster DL, Bucholtz DC, Herbosa CG. Metabolic signals and the timing of puberty in sheep. In: Plant TM, Lee PA (Eds), The neurobiology of puberty, Society for Endocrinology, Bristol, 1995, p 243-257.

[43] Casanueva FF, Dieguez C. Neuroendocrine regulation and actions of leptin. Frontiers in Neuroendocrinology 1999, 20: 317-363.

[44] Zieba DA, Amstalden M, Williams GL. Regulatory roles of leptin in reproduction and metabolism: A comparative review. Domest Anim Endocrinol 2005, 29: 166185.

[45] Woods SC, Seeley RJ. Hormonal mediation of energy homeostasis in obesity, diabetes and related disorders. Drug Discovery Today: Disease Mechanisms 2005, 2: 321326.

[46] Woods SC, Benoit SC, Clegg DJ, Seeley RJ. Regulation of energy homeostasis by peripheral signals. Best Pract Res Clin Endocrinol Metab 2004, 18: 497-515.

[47] Finn PD, Cunningham MJ, Pau KYF, Spies HG, Clifton DK, Steiner RA. The stimulatory effect of leptin on the neuroendocrine reproductive axis of the monkey. Endocrinology 1998, 139: 4652-4662.

[48] Schwartz GJ. The role of gastrointestinal vagal afferents in the control of food intake: current prospects. Nutrition 2000, 16: 866873.

[49] Iqbal J, Pompolo S, Murakami T, Grouzmann E, Sakurai T, Meister B, Clarke IJ. Immunohistochemical characterization of localization of long-form leptin receptor $(\mathrm{OB}-\mathrm{Rb})$ in neurochemically defined cells in the ovine hypothalamus. Brain Res 2001, 920: 55-64.

[50] Taylor MM, Samson WK. The other side of the orexins: endocrine and metabolic actions. Am J Physiol 2003, 284: E13-E17.

[51] Irwig MS, Fraley GS, Smith JT, Acohido BV, Popa SM, Cunningham MJ, Gottsch ML, Clifton DK, Steiner RA. Kisspeptin activation of gonadotropin releasing hormone neurons and regulation of KiSS-1 mRNA in the male rat. Neuroendocrinology 2004, 80: 264-272. 
[52] Gottsch ML, Cunningham MJ, Smith JT, Popa SM, Acohido BV, Crowley WF, Seminara S, Clifton DK, Steiner RA. A role for kisspeptins in the regulation of gonadotropin secretion in the mouse. Endocrinology 2004, 145: 4073-4077.

[53] Navarro VM, Castellano JM, FernandezFernandez R, Tovar S, Roa J, Mayen A, Barreiro ML, Casanueva FF, Aguilar E, Dieguez C, Pinilla L, Tena-Sempere M. Effects of KiSS-1 peptide, the natural ligand of GPR54, on follicle-stimulating hormone secretion in the rat. Endocrinology 2005, 146: 1689-1697.

[54] Rawson JA, Scott CJ, Pereira A, Jakubowska A, Clarke IJ. Noradrenergic projections from the A1 field to the preoptic area in the brain of the ewe and Fos responses to oestrogen in the A1 cells. J Neuroendocrinol 2001, 13: 129-138.

[55] Zieba DA, Amstaldem M, Maciel MN, Keisler DH, Raver N, Gertler A, Williams GL. Divergent effects of leptin on luteinizing hormone and insulin secretion are dose dependent. Exp Biol Med 2003, 228: 325330.

[56] Henry BA, Goding JW, Tilbrook AJ, Dunshea F, Clarke IJ. Intracerebroventricular infusion of leptin elevates the secretion of luteinising hormone without affecting food intake in long-term food-restricted sheep, but increases growth hormone irrespective of bodyweight. J Endocrinol 2001, 168: 67-77.

[57] Tena-Sempere M, Pinilla L, Zhang FP, Gonzalez LC, Huhtaniemi I, Casanueva FF, Dieguez C, Aguilar E. Developmental and hormonal regulation of leptin receptor $(\mathrm{Ob}-$ $\mathrm{R})$ messenger ribonucleic acid expression in rat testis. Biol Reprod 2001, 64: 634-643.

[58] Tena-Sempere M, Pinilla L, González LC, Diéguez C, Casanueva FF, Aguilar E. Leptin inhibits testosterone secretion from adult rat testis in vitro. J Endocrinol 1999, 161: 211218.

[59] Sugino T, Hasegawa Y, Kurose Y, Kojima M, Kangawa K, Terashima Y. Effects of ghrelin on food intake and neuroendocrine function in sheep. Anim Reprod Sci 2004, 82-83: 183-194.

[60] St-Pierre DH, Wang L, Tache Y. Ghrelin: a novel player in the gut-brain regulation of growth hormone and energy balance. News Physiol Sci 2003, 18: 242-246.

[61] Fernandez-Fernandez R, Tena-Sempere M, Aguilar E, Pinilla L. Ghrelin effects on go- nadotropin secretion in male and female rats. Neurosci Lett 2004, 362: 103-107.

[62] Tena-Sempere M. Exploring the role of ghrelin as novel regulator of gonadal function. Growth Horm IGF Res 2005, 15: 83-88.

[63] Gonzalez LC, Pinilla L, Tena-Sempere M, Aguilar E. Leptin(116-130) stimulates prolactin and luteinizing hormone secretion in fasted adult male rats. Neuroendocrinology 1999, 70: 213-220.

[64] Amstalden M, Zieba DA, Edwards JF, Harns PG, Welsh TH, Stanko RL, Williams GL. Leptin acts at the bovine adenohypophysis to enhance basal and gonadotrophin-releasing hormone-mediated release of luteinizing hormones: differential effects are dependent upon nutritional history. Biol Reprod 2003, 69: 1539-1544.

[65] Asakuma S, Morishita H, Sugino T, Kurose Y, Kobayashi S, Terashima Y. Circulating leptin response to feeding and exogenous infusion of insulin in sheep exposed to thermoneutral and cold environments. Comp Biochem Physiol A Mol Integr Physiol 2003, 134: 329-335.

[66] Diez JJ, Iglesias P. The role of the novel adipocyte-derived hormone adiponectin in human disease. Eur J Endocrinol 2003, 148: 293-300.

[67] Clarke IJ, Tilbrook AJ, Turner AI, Doughton BW, Goding JW. Sex, fat and the tilt of the earth: effects of sex and season on the feeding response to centrally administered leptin in sheep. Endocrinology 2001, 142: 27252728.

[68] Hötzel MJ, Walkden-Brown SW, Fisher JA, Martin GB. Determinants of the annual pattern of reproduction in mature male Merino and Suffolk sheep: response to a nutritional stimulas in the breeding and non-breeding season. J Reprod Fertil 2003, 15: 1-9.

[69] Chagas L, Blache D, Blackberry MA, Sharma TP, Martin GB. Does glucose infusion affect the CSF concentrations of insulin and gonadotrophin secretion in mature rams. Proc Aust Soc Reprod Biol 1997, 28: 15.

[70] Chagas L, Blache D, Blackberry MA, Tellam R, Vercoe PE, Martin GB. Plasma concentrations of leptin are increased in male sheep fed a diet that stimulates the secretion of $\mathrm{LH}$ pulses. Proc End Soc Aust 1999, 42: 86.

[71] Chagas L, Blache D, Blackberry MA, Martin GB. Does insulin or leptin mediate the effect of dietary fatty acids on LH pulse frequency in mature male sheep? Proc Aust Soc Reprod Biol 1999, 30: 56. 